\title{
Effect of Low-Fat Diets Enriched with Fruit Purees on the Biochemical Markers of Metabolic Syndrome Analogy Induced-Rats
}

\author{
Efecto de Dietas Bajas en Grasa Enriquecida con Purés de Frutas sobre Marcadores \\ Bioquímicos en Ratas Inducidas con Analogia a Sindrome Metabólico
}

Úrsula Mireya Morales-Ávila ${ }^{1}$ Elhadi M. Yahia²; Rubén Montalvo-González ${ }^{3}$; Eduardo Mendeleev Becerra-Verdín ${ }^{3}$ \& Efigenia Montalvo-González ${ }^{1}$

MORALES-ÁVILA, U. M.; YAHIA, E. M.; MONTALVO-GONZÁLEZ, R.; BECERRA-VERDÍN, E. M. \& MONTALVOGONZÁLEZ, E. Effect of low-fat diets enriched with fruit purees on the biochemical markers of metabolic syndrome analogy inducedrats. Int. J. Morphol., 38(1):61-68, 2020.

SUMMARY: Fruit purees can be added to diet as alternative sources of bioactive compounds for the prevention and/or improvement of the complications of metabolic syndrome. In this work we evaluated the effect of the intake of low-fat diets enriched with fruit purees (guava-strawberry, guava-blackberry, guava-soursop, guava-passion fruit) on the body weight and biochemical markers in metabolic syndrome analogy (MSA)-induced rats. The rats ( $n=6$ for each treatment) were induced with a high fat diet and were injected with streptozotocin, one dose every week for 4 consecutive weeks after fasting overnight, then healthy rats were fed with standard diet and MS rats were fed with standard diet plus each of the fruit puree, for 4 weeks. As novel findings, the diet enriched with fruit purees was associated with a reduction in body weight ( 13-21\%) and a control in the metabolism of glucose by decreasing plasma glucose ( 59$63 \%)$. Also, there was a reduction in the total cholesterol, triacylglycerols, low-density lipoproteins, and low enzymatic activities of alanine aminotransferase, alkaline phosphatase and $\gamma$-glutamyl transferase, useful metabolites in the control of inflammatory processes in the liver. A notable improvement in the liver morphology was observed indicating that the treatments had a hepatoprotective effect. The diet enriched with guava-blackberry puree caused the best results on most biochemical markers of MS rats. Therefore, diets enriched with fruit purees can be an alternative for MS individuals for the control and improvement of the complications caused by this syndrome.

KEY WORDS: Biochemical markers; Fruit purees; Hepatoprotective effect; Metabolic syndrome.

INTRODUCTION

The development of metabolic syndrome (MS) is highly related to abdominal obesity and insulin resistance. MS is a silent disease, its adverse effects are insidious, and although it is theoretically treatable with modern medical management and lifestyle modification, significant improvements have not been achieved (World Health Organization, 2016). Obesity, vascular dysfunction, diabetes mellitus, hyperglycemia and hypertension are included in MS and clinically, MS is observed with elevated triacylglycerols, a significant increase in very low-density lipoprotein-cholesterol (VLDL-C), low-density lipoproteincholesterol (LDL-C), and a decrease in HDL lipoprotein, hyperglycemia, and failure of insulin action (Siriwardhana et al., 2013).

In vivo assays indicated that dietary bioactive compounds such as dietary fiber, phenolic compounds, carotenoids, vitamins and minerals in fruits and vegetables have the ability to reduce the markers of metabolic risks (Ullah et al., 2016). The majority of the available scientific evidence is based on the effects of the intake of fresh fruits or extracts of their components. However, there is an increased demand of elaborated and processed products that are easily accessible, ready to eat, and may also provide

\footnotetext{
${ }^{1}$ Laboratorio Integral de Investigación en Alimentos, Tecnológico Nacional de México/Instituto Tecnológico de Tepic, Tepic, Nayarit, México.

${ }^{2}$ Facultad de Ciencias Naturales, Universidad Autónoma de Querétaro, Querétaro, México.

${ }^{3}$ Laboratorio de Investigación Clínica e Histología, Universidad Autónoma de Nayarit, Tepic Nayarit, México.
} 
health benefits. There are very limited studies on the potential benefits of processed fruits such as fruit purees on the prevention or decrease in the MS risk markers.

Pérez-Beltrán et al. (2017) investigated the effect of the intake of fruit purees (guava-strawberry, guavablackberry, guava-soursop fruit and guava-passion fruit) on the biochemical markers of rats with metabolic disorders, and demonstrated that all purees decreased plasma glucose (32-37\%) in hyperglycemic rats and total cholesterol and triacylglycerols in hypercholesterolemic rats, and concluded that the fruit purees could exert a beneficial effects. Derived from our previous study and that we did not induce obese rats and the hyperglycemia in rats was induces with a dose of streptozotocin (STZ), it was important to evaluate the effect of fruit purees on individuals with chronic diseases. Therefore, the objective of this work was to evaluate the effects of the intake of a fat-low diets enriched with fruit purees on the biomarkers in MS analogy-induced rats.

\section{MATERIAL AND METHOD}

Fruit purees and diets. Four purees: guava-strawberry (GSP), guava-blackberry (GBP), guava-soursop fruit (GSSP) and guava-passion fruit (GPP) purees, were donated by the company Purés y Derivados de Nayarit (PDN), Camichin de Jauja, Nayarit, Mexico. Bags of $450 \mathrm{~g}$ of each puree were used in the experiment. Five diets were used. A commercial pedestrian maintenance diet for the experimentation (Nutri cubo Purina ${ }^{\circledR}$; Purina Tepic, Nayarit, Mexico) was considered as the standard rodent diet (StD). Other diet was a high fat diet (HF-StD), which was prepared with StD (500 g) and fried for $20 \mathrm{~min}$ with $500 \mathrm{~g}$ of commercial pork lard. The other four diets were prepared with StD without frying, and enriched with a type of fruit puree.

Animals and experimental groups. Animals were provided by the Institute of Neurobiology of the Universidad Nacional Autónoma de México (Queretaro, Mexico). The State Bioethics Committee of Nayarit, Mexico approved the experimental protocol (No. CENB/03/2017), in addition of following the protocols of the Institutional Animal Care and Use Committee, according to the Mexican law (NOM062-ZOO-1999) (Diario Oficial, 2001). Thirty-six adult female Wistar rats $(245 \pm 5 \mathrm{~g})$ were used in this experiment. They were placed in individual cages and kept under ambient conditions $\left(23 \pm 1{ }^{\circ} \mathrm{C}, 60 \pm 10 \%\right.$ relative humidity), with periods of light and darkness of $12 \mathrm{~h}$ each. The animals were fed with StD and water ad libitum. After one week of acclimation the animals were randomized into six groups of six rats each.
The healthy control group was fed with $15 \mathrm{~g} \mathrm{StD}$ and water ad libitum during all the experiment. To induce MSA, the rats were fed with $15 \mathrm{~g} \mathrm{HF}-\mathrm{StD}$ every day for 4 weeks to induce obesity. After obesity induction, the rats were induced to hyperglycemia, injected four times with intraperitoneal injections of streptozotocin (STZ, Sigma-Aldrich, St. Louis, MO), one injection every week for 4 consecutive weeks after fasting overnight. The rats were then injected with STZ at $65 \mathrm{mg} / \mathrm{kg}$ which was dissolved in citrate buffer $(\mathrm{pH} 4.5)$. During the MS induction, the rats were fed with $15 \mathrm{~g} \mathrm{HF}$ StD every day. At the end of MS induction, the rats were weighted, and glucose and insulin analysis were performed to corroborate MS analogy induction. After $8 \mathrm{~h}$ of fasting, tail vein blood samples were collected to determine blood glucose levels and insulin. At the end of the induction period (8 weeks), the HF-StD diet was removed and MS rats were divided into six groups,: Group I: Healthy group fed with StD (H-StD); Group II: Metabolic syndrome group fed with StD (MSA-StD); Group III: Metabolic syndrome group fed with StD + guava-strawberry puree (MSA-StD + GSP); Group IV: Metabolic syndrome group fed with StD + guavablackberry puree (MSA-StD + GBP); Group V: Metabolic syndrome group fed with StD + guava-soursop fruit puree (MSA-StD + GSSP); Group VI: Metabolic syndrome group fed with StD + guava-passion fruit puree (MSA-StD + GPP).

Over the dietary intervention period, the diets and water were administrated orally ad libitum. The daily quantities of diet for 4 weeks were: $15 \mathrm{~g} \mathrm{StD}$ to the H-StD and MSA-StD groups, while others MS groups were fed with $13 \mathrm{~g}$ StD enriched with $2 \mathrm{~g}$ of a type of fruit puree. The food intake of the rats was recorded daily, and all of them consumed 15 g every day, and their body weights were monitored each week throughout the experimental duration. After 12 weeks, the euthanasia was practiced in the animals with $12 \mathrm{~h}$ of fasting to obtain blood and hepatic tissue. The euthanasia protocol followed was according to the Manual on the Use and Care of Experimental Animals (NOM-062ZOO-1999) (Diario Oficial). Blood samples were obtained by puncture in the inferior vena cava. The serum samples were obtained by centrifugation of blood samples $(1.5 \mathrm{~mL})$ at $4500 \mathrm{xg}$ for $5 \mathrm{~min}$ at $4{ }^{\circ} \mathrm{C}$, and were analyzed before $7 \mathrm{~h}$, in order to comply with the quality control requirements of the clinical biochemical test.

\section{Plasma glucose, insulin, liver enzymes and other} metabolites. The concentration of plasma glucose, insulin, the enzyme activities of aspartate aminotransferase (AST), alanine aminotransaminase (ALT), $\gamma$-gamma glutamyl transferase (GGT) and alkaline phosphatase (FA), as well as glycosylated hemoglobin (HbA1c), urea, creatinine, uric acid, total proteins (TP) and albumin were performed according to the methods of the International Federation of 
Clinical Chemistry using enzymatic colorimetric kits (Biosystems Reagents and Instruments, Barcelona, Spain) and a calibrated Biosystem Auto-analyzer (BTS-350, Barcelona, Spain). Insulin level was measured in plasma using the sensitive rat insulin radioimmunoassay kit (Linco Research, Inc., St. Charles, MO, USA).

Lipid profile. Total cholesterol (TC), triacylglycerols (TG), and high-density lipoprotein cholesterol (HDL-C) were determined in serum samples using enzymatic colorimetric kits (Biosystems Reagents and Instruments, Barcelona, Spain) with the Biosystem Auto-analyzer. The LDL-C and VLDL-C fractions were determined according to the Friedewald equations (Siri-Tarino \& Krauss, 2016).

Histopathological study of the liver. The liver was fixed in $10 \%$ neutral-buffered formalin ( $\mathrm{pH}$ 6.8), embedded in paraffin through a Leica Biosystems TP1020 tissue processor (Nussloch, Germany). The tissues were sectioned with a Leica RM2125RTS microtome (Nussloch, Germany) and stained with hematoxylin and eosin. The sections were analyzed by Leica DME1359 light microscope (Wetzlar, Germany) (60x).

Statistical analysis. The in vivo data were analyzed by the Kruskal-Wallis test $(\mathrm{p}<0.05)$. All statistical analyses were performed using the statistical software STATISTICA (v.10 StatSoft, Tulsa, OK).

\section{RESULTS AND DISCUSSION}

Body weight, plasma glucose, insulin and other metabolites. The body weight of $\mathrm{StD}$ group was maintained without changes ( $p>0.05)$ until the end of the experiment (Table I). However, in the MS group the total food intake and the body weight increased ( 24-28\%). The increase in body weight is the result of excess of caloric intake and a decrease in caloric expenditure (Carillon et al., 2013). After the fat content was reduced in the diet, the body weight of all MS groups fed with StD MSA-StD+FP was reduced from $13 \%$ to $21 \%$, coinciding with the decrease of their total food intake, and the reduction was higher in the MSA$\mathrm{StD}+\mathrm{GPP}$ group. The body weight reduction is attributed to the consumption of fruit purees, because in the MSA-StD group the body weight did not decrease. It is possible that low fat diets with indigestible fraction and bioactive compounds caused beneficial effects, such as reduction of carbohydrates absorption, induction of satiogenic effect, as well as potential activation of thermogenesis and inflammatory processes, especially in individuals with an increased risk for metabolic syndrome (Ullah et al.).

The plasma glucose from MSA-StD group was $348.33 \mathrm{mg} / \mathrm{dL}$, and was higher than the H-StD group (77.83 $\mathrm{mg} / \mathrm{dL}$ ). This increase could be related to the concentration of the hormone responsible for glucose metabolism (insulin), which decreased $34 \%(7.76 \mathrm{mg} / \mathrm{dL})$ in the MSA-StD group with respect to the $\mathrm{H}-\mathrm{StD}$ group $(11.83 \mathrm{mg} / \mathrm{dL})$. In addition, this imbalance caused an increase in glycosylated hemoglobin in the MSA-StD group (11.94\%) with a significant difference $(\mathrm{p}<0.05)$ compared to the H-StD group (3.84\%). In a diabetic individual, the levels of these biochemical markers are maintained during a period of 3 months (Brownlee et al., 2016), and therefore, the plasma glucose concentration in the MSA-StD group was not regularized for 4 weeks. This is probably caused by the deficit in the secretion and/or action of insulin.

A notable change in the glucose and insulin concentration from MSA-StD+FP groups was observed. The decrease in glucose was $\sim 59-63 \%$, and the increase in insulin was $\sim 11-36 \%$, with values similar to those of the H-StD

Table I. Body weight and biochemical biomarkers for healthy animals fed with standard diet (H-StD), metabolic syndrome analogy inducedanimals fed with standard diet (MSA-StD), and metabolic syndrome analogy induced-animals fed with standard diet and guava-strawberry $($ MSA-StD + GSP), guava-blackberry (MSA-StD + GBP), guava-soursop fruit (MSA-StD + GSSP) or guava-passion fruit (MSA-StD + GPP) puree.

\begin{tabular}{|c|c|c|c|c|c|c|}
\hline Parameters & $\mathrm{H}-\mathrm{StD}$ & MSA-StD & MSA-StD+GSP & MSA-StD+GBP & MSA-StD+GSSP & MSA-StD+GPP \\
\hline \multicolumn{7}{|l|}{ Body weight (g) } \\
\hline Initial & $245.00 \pm 4.58 \mathrm{a}^{\mathrm{bX}}$ & $247.33 \pm 7.02 \mathrm{a}^{\mathrm{bX}}$ & $251.33 \pm 6.42 b^{x}$ & $241.00 \pm 9.53 \mathrm{a}^{\mathrm{bX}}$ & $238.00 \pm 2.00 \mathrm{ax}$ & $245.33 \pm 3.05^{\mathrm{ab} x}$ \\
\hline After induction of MS & $243.33 \pm 4.16 \mathrm{~b}^{\mathrm{X}}$ & $307.33 \pm 6.42 \mathrm{aY}$ & $304.66 \pm 2.51 \mathrm{aY}$ & $305.66 \pm 2.51 \mathrm{aY}$ & $308.66 \pm 1.52 \mathrm{aY}$ & $308.33 \pm 1.15^{\mathrm{aY}}$ \\
\hline End of treatment & $246.66 \pm 5.77 \mathrm{a}^{\mathrm{bX}}$ & $300.33 \pm 1.52 \mathrm{eY}$ & $263.66 \pm 4.04 \mathrm{~d}^{\mathrm{X}}$ & $260.66 \pm 0.57 \mathrm{c}^{\mathrm{dX}}$ & $252.66 \pm 7.09^{\mathrm{bcX}}$ & $243.66 \pm 5.50^{\mathrm{ab} x}$ \\
\hline \multicolumn{7}{|l|}{ Biochemical parameter (mg/dL) } \\
\hline Glucose & $77.83 \pm 2.22 b$ & $348.33 \pm 21.46^{\mathrm{c}}$ & $133.00 \pm 11.93 \mathrm{a}$ & $126.00 \pm 8.09 \mathrm{a}$ & $136.33 \pm 8.01^{\mathrm{a}}$ & $142.50 \pm 27.14^{\mathrm{a}}$ \\
\hline Insulin & $11.83 \pm 2.41 \mathrm{a}$ & $7.76 \pm 1.22^{\mathrm{b}}$ & $11.00 \pm 1.33^{\mathrm{a}}$ & $12.26 \pm 0.73 \mathrm{a}$ & $9.88 \pm 0.91^{\mathrm{c}}$ & $8.76 \pm 0.89 \mathrm{c}$ \\
\hline Glycosylated hemoglobin (HbA1c) ${ }^{a}$ & $3.84 \pm 0.41 \mathrm{~b}$ & $11.94 \pm 1.24^{\mathrm{c}}$ & $5.65 \pm 1.30^{\mathrm{a}}$ & $5.67 \pm 1.14 \mathrm{a}$ & $5.27 \pm 1.07^{\mathrm{a}}$ & $5.65 \pm 1.56 \mathrm{a}$ \\
\hline Urea & $55.01 \pm 11.20^{\mathrm{b}}$ & $44.66 \pm 2.62^{\mathrm{a}}$ & $37.83 \pm 1.32^{\mathrm{c}}$ & $44.83 \pm 2.71 \mathrm{a}$ & $45.33 \pm 3.20^{\mathrm{a}}$ & $42.83 \pm 2.22 \mathrm{a}$ \\
\hline Uric Acid & $2.67 \pm 0.91 \mathrm{~d}$ & $2.47 \pm 0.20^{\mathrm{cd}}$ & $1.41 \pm 0.14^{\mathrm{a}}$ & $1.33 \pm 0.42 \mathrm{a}$ & $1.97 \pm 0.30^{\mathrm{bc}}$ & $1.62 \pm 0.34 \mathrm{ab}$ \\
\hline Creatinine & $0.65 \pm 0.05 \mathrm{a}$ & $0.86 \pm 0.05^{\mathrm{b}}$ & $0.63 \pm 0.08^{\mathrm{a}}$ & $0.68 \pm 0.07 \mathrm{a}$ & $0.61 \pm 0.07^{\mathrm{a}}$ & $0.65 \pm 0.10 \mathrm{a}$ \\
\hline
\end{tabular}

aHbA1c: percentage (\%). Data are means of three independent repetitions \pm standard error. Different lowercase letters (a, b, c, d) indicate significant differences $(p<0.05)$ between treatments and uppercase letters $(X, Y, Z)$ indicate significant differences $(p<0.05)$ between time of treatments. 
group. Although it was notable that StD+GSP and StD+GBP diets had the highest significant effect. The results coincided with the decrease of HbA1c ( $52-55 \%)$. Different reports have demonstrated the effective reduction of glucose after treatment with guava extracts rich in phenolic compounds such as chlorogenic acid, gallic acid, quercetin, myricetin and rutin (Díaz-de-Cerio et al., 2017). Bioactive compounds and dietary fiber and/or indigestible fraction may increase the activity of carbohydrate and lipid digestive enzymes such as a-glucosidase and a-amylase, the pancreatic lipase activity and angiotensin I-converting enzyme and the inhibition of serine protease dipeptidyl peptidase IV (DP-IV) (Liu et al., 2009).

The analysis of biomarkers such as urea, creatinine and uric acid are useful for the control of renal function in patients with metabolic syndrome (Khanam et al., 2017). Table I shows the concentrations of these serum metabolites.
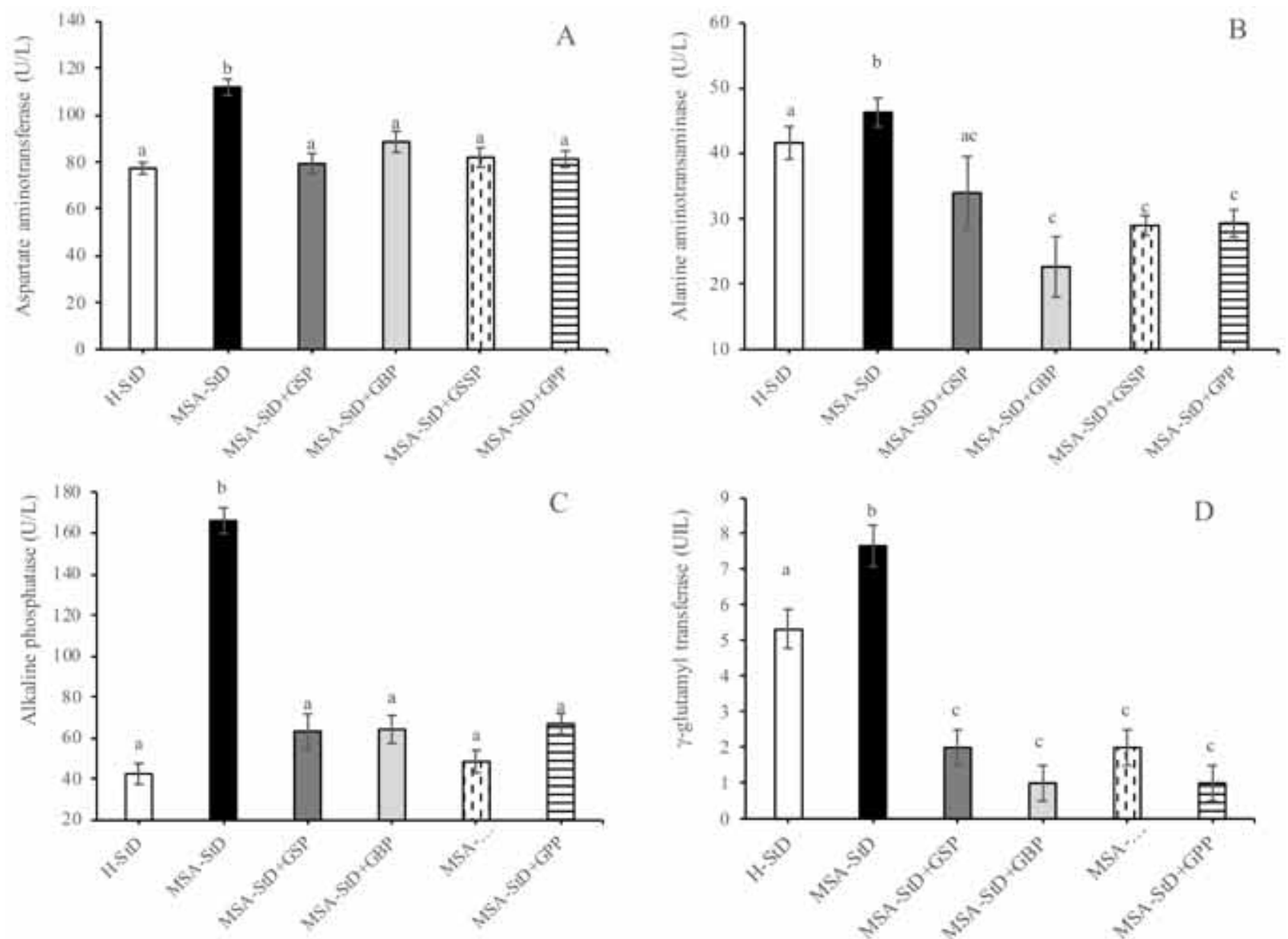

Fig. 1. Aspartate aminotransferase (A), alanine aminotransaminase (B), alkaline phosphatase (C) and $\gamma$-glutamyl transferase (D) activities in healthy rats fed with standard diet $(\mathrm{H}-\mathrm{StD})$, metabolic syndrome analogy-induced rats fed with StD (MSA-StD), and metabolic syndrome analogy-induced rats fed with StD plus guava-strawberry (MSA-StD+GSP), guava-blackberry (MSA-StD+GBP), guavasoursop fruit (MSA-StD+GSSP) or guava-passion fruit (MSA-StD+GPP) puree. 
compounds present in the purees. The bioactive compounds have been reported to induce a positive effect in reducing kidney failure (Jankovic et al., 2015).

Liver enzymes. AST is found in the cytoplasm and mitochondria of the hepatocyte, and an increase in its activity indicates an apoptosis or cell lysis caused by an increase in the absorption of fats by the hepatocyte (Fishbein et al., 2013). Figure 1A shows that AST activity increased $43 \%$ in the MSA-StD group (112 U/L) with respect to H-StD group (77.33 U/L). The enzymatic activity increase can be caused by the decrease in the concentration or action of the antioxidant enzymes present in the hepatocytes or lipotoxicity (Carillon et al.; Maulucci et al., 2016). After 4 weeks of consumption of fruit purees (GSP, GBP, GSSP or GPP) with the diets of the different groups, a decrease of $\sim 23 \%$ in the AST activity was observed with similar values to H-StD group. The beneficial effect of polyphenols is directly related to hepatic regeneration, since they have a direct ratio with the concentration of histone deacetylase enzymes (at the DNA level) present in hepatocytes, and therefore they have a hepatoprotective activity because they inhibit the cycle of induction to cellular apoptosis (Vahid et al., 2015).

Figure 1B shows the activity of ALT. An increase in the activity of this enzyme indicates extra-hepatic or intrahepatic obstructive disorder caused by inflammatory conditions in the liver (Fishben et al., 2003). The ALT activity was 41.6 U/L in the H-StD group and 46.33 U/L in the MSAStD group. A high ALT activity in the MSA-StD group indicates damage to the liver, causing an increase in serum ALT activity (Fishben et al., 2003). Nevertheless, ALT activity decreased in MS groups fed with StD+FP diets (Fig. $1 \mathrm{~B})$, and the percentage of reduction was 26.6-36.7\% $(\mathrm{p}<0.05)$. This indicates that the consumption of fruit purees had a significant effect in decreasing ALT activity, probably due to the content of bioactive compounds in the diets. Several reports have demonstrated that polyphenols increased the expression of genes that contribute to the hepatoprotective effect, if the liver is regenerated, the ALT activity decreases (de Oliveira et al., 2016). It is probable that the consumption of fruit purees improves the inflammatory systemic conditions, and for this reason a decrease in the ALT activity was observed.

Figures 1C and 1D show the ALP and GGT activities. ALP activity was higher in the MSA-StD group (166 U/L) than in the H-StD (42.6 U/L) and MSA-StD+FP (48.66-67.0 $\mathrm{U} / \mathrm{L})$ groups. This enzyme is found in the sinusoidal membranes and in the bile canaliculi of liver; and therefore, an increase of its activity indicates a relation with hepatobiliary disorders (Houben et al., 2017). In the same way, the GGT activity was higher in MSA-StD group (7.66 $\mathrm{U} / \mathrm{L})$ than in the H-StD (5.33 U/L) or the MSA-StD+FP (1.0$2.0 \mathrm{U} / \mathrm{L})$ groups. This enzyme is found particularly in the bile canaliculi (Rubin \& Strayer, 2012), and therefore, an increase in its activity indicates biliary obstruction, as probably occur in the MSA-StD group. The low ALP and GGT activities ( 44\%) in the MSA-StD+FP groups might be related to an anti-inflammatory effect of the bioactive compounds present in the functional food matrix. It has been reported that this effect is counteracted with the action of bioactive compounds such as flavonoids (catechins, quercetins and isoflavones) present in the fruit matrix (Shahidi \& Ambigaipalan, 2015). There were no significant differences $(p>0.05)$ in the concentrations of total proteins (Fig. 2A) and albumin (Fig. 2B) of the experimental groups, although there was a tendency of an increase in the MSAStD+FP groups. The proteins are synthesized and excreted by the liver for increasing the transport of nutrients, lipid metabolism and the excretion of unwanted metabolites (Jin et al., 2016).

Lipid profile. Unlike the H-STD group, the TC value increased $65 \%$ in the MSA-StD group, which caused an increase in LDL-C (41.33 mg/dL) and VLDL-C (35 mg/dL) (Table II). Also, the TG concentration increased in the MSAStD group (175 mg/dL) with a significant difference ( $\mathrm{p}$ ?0.05) with respect to the H-StD group ( $42 \mathrm{mg} / \mathrm{dL})$. Any of the following components are required for the diagnosis of metabolic syndrome: high levels of triglycerides, reduced levels of HDL-C and fasting hyperglycemia (Tsitsimpikou et al., 2014). High values of TG, LDL-C, VLDL-C and a

Table II. Lipid profile for healthy rats fed with standard diet (H-StD), metabolic syndrome analogy induced-animals fed with standard diet (MSA-StD), and metabolic syndrome analogy-induced animals fed with standard diet and guava-strawberry (MSA-StD + GSP), guava-blackberry (MSA-StD + GBP), guava-soursop fruit (MSA-StD + GSSP) or guava-passion fruit (MSA-StD + GPP) puree.

\begin{tabular}{lrrrrrr}
\hline Parameters (mg/dL) & \multicolumn{1}{c}{ H-StD } & MSA-StD & MSA-StD+GSP & MSA-StD+GBP & MSA-StD+GSSP & MSA-StD+GPP \\
\hline Total Cholesterol & $54.33 \pm 8.31^{\mathrm{b}}$ & $90.00 \pm 5.56 \mathrm{c}$ & $65.33 \pm 1.15^{\mathrm{ab}}$ & $68.33 \pm 4.72^{\mathrm{a}}$ & $71.00 \pm 1.73 \mathrm{a}$ & $71.66 \pm 1.52 \mathrm{a}$ \\
HDL- Cholesterol & $42.00 \pm 6.24^{\mathrm{c}}$ & $13.66 \pm 4.72^{\mathrm{a}}$ & $22.66 \pm 3.05^{\mathrm{ab}}$ & $26.66 \pm 2.51^{\mathrm{b}}$ & $24.00 \pm 4.64 \mathrm{a}$ & $19.33 \pm 2.08^{\mathrm{ab}}$ \\
LDL-Cholesterol & $5.10 \pm 1.13^{\mathrm{c}}$ & $41.33 \pm 3.18^{\mathrm{d}}$ & $19.0 \pm 0.69^{\mathrm{b}}$ & $26.00 \pm 2.51^{\mathrm{a}}$ & $26.73 \pm 1.80 \mathrm{a}$ & $27.60 \pm 1.50 \mathrm{a}$ \\
VLDL-Cholesterol & $8.40 \pm 0.97^{\mathrm{c}}$ & $35.00 \pm 0.75^{\mathrm{d}}$ & $23.06 \pm 0.61 \mathrm{a}$ & $16.00 \pm 1.00^{\mathrm{b}}$ & $20.26 \pm 0.23 \mathrm{ab}$ & $24.73 \pm 1.36 \mathrm{a}$ \\
Triacylglycerols & $42.00 \pm 1.00 \mathrm{f}$ & $175.00 \pm 3.78^{\mathrm{a}}$ & $115.33 \pm 3.05 \mathrm{c}$ & $107.00 \pm 2.00^{\mathrm{d}}$ & $94.66 \pm 1.15 \mathrm{e}$ & $123.66 \pm 6.80 \mathrm{~b}$ \\
\hline
\end{tabular}

Data are means obtained from three replicates \pm standard error. Different superscript letters in the same file indicate significant differences $(\mathrm{p}<0.05)$. 

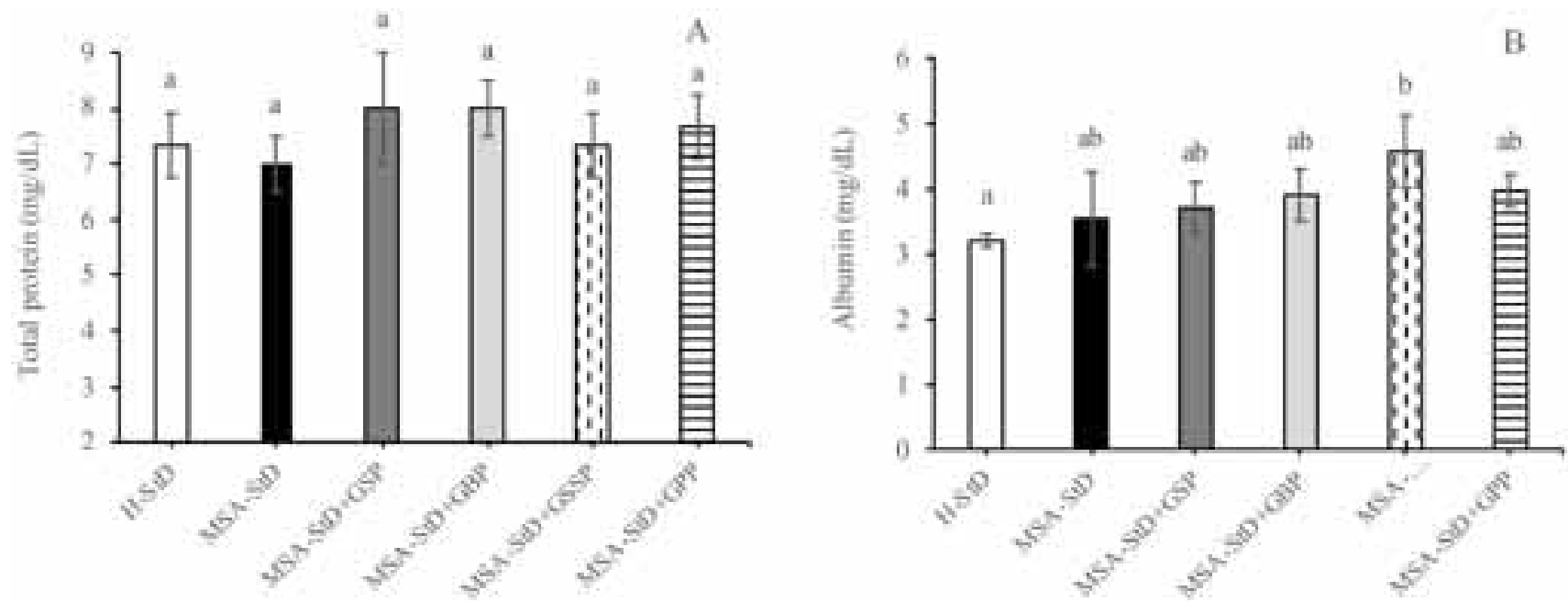

Fig. 2. Total protein (A), albumin (B) in healthy rats fed with standard diet (H-StD), metabolic syndrome analogy-induced rats fed with StD (MSA-StD) and metabolic syndrome analogy-induced rats fed with StD plus guava-strawberry (MSA-StD+GSP), guava-blackberry (MSA-StD+GBP), guava-soursop fruit (MSA-StD+GSSP) or guava-passion fruit (MSA-StD+GPP) puree.

decrease in HDL-C from serum of MSA-StD group were observed despite that the diet was changed with StD without fat after 4 weeks. A control of this pathology is initially caused by a decrease in fat intake, since fatty acids are the main supply for the formation of triglycerides and VLDL$\mathrm{C}$, responsible for the formation of atheromatous plaques (Sawicka et al., 2016). A decrease in the concentration of TC (20-27 \%), LDL-C (37-54 \%), VLDL-C (29-54\%) and TG (29-45\%), as well as a notable increase in HDL-C concentration such as $65 \%$ in the MSA-StD+GSP group, $95 \%$ in the MSA-StD+GBP group, $75 \%$ in the MSAStD+GSSP group, and $41 \%$ in the MSA-StD+GPP group were observed. The results were dependent on the kind fruit puree, being GBP causing the highest HDL-C synthesis in MSA-induced rats. GBP had the highest content of polyphenols (Pérez-Beltrán et al.). The polyphenol-enriched diet (principally from berries) has shown to significantly improve the oxidative stress markers by decreasing lipid peroxidation and ameliorating the serum lipid profile of subjects through a reduction of total cholesterol, LDL-C, and triacylglycerol levels in healthy and dyslipidemic subjects. Cyanidin 3-O-b-d-glucoside-rich blackberries modulate hepatic gene expression, and has anti-obesity effects (Klimis-Zacas et al., 2016). Therefore, polyphenols seem to be the most likely constituents exerting in vivo effects in the prevention of cardiovascular disease risk.

Histological findings. The normocitic and normocromic hepatocytes, with uniform size and color and with homogeneous sinusoidal spaces are shown in the microphotography of the H-StD group liver (Fig. 3A). Fi- gure 3B shows the histological findings of the MSA-StD group. The population of hepatocytes decreased and presented a nucleus greater than the hepatocytes of the $\mathrm{H}$ $\mathrm{StD}$ group. It can also be observed that there are numerous blank spaces, which are deposits of fat. It is possible that the glucotoxicity and lipoptoxicity caused insulin resistance, which in turn caused an increase in the production of reactive oxygen species (ROS), damaging the lipid membrane of the liver cells (Maulucci et al.).

After MSA-induced rats were subjected to 4 weeks of treatment (Figs. 3C-F), numerous changes in the liver structure have been observed. The histological analysis showed a marked improvement in the liver of the animals of these groups, homogeneous hepatocyte cells, normocytic and normo-cromic endothelial cells, and normal hepatic sinusoids. Also, there was a decrease in the number of intracellular vesicles, which represent a decrease in lipid deposits. The potential effect of the addition of fruit purees to the diet was confirmed, considering that the high content of dietary fiber and bioactive compounds together decrease the oxidative stress and inhibit the ROS toxicity. The consumption of GBP, GSSP and GPP caused a greater number of liver cells. The effect of various compounds such as resveratrol, epigallocatechin-3-gallate (EGCG), quercetin, ellagitannins, organosulforates has been reported at the DNA level, acting in a direct proportional relationship with the concentration of histone deacetylase enzymes with respect to the population of hepatocytes (Vahid et al.). The highest polyphenol content was observed in GBP, GSSP and GPP (Pérez-Beltrán et al.). 

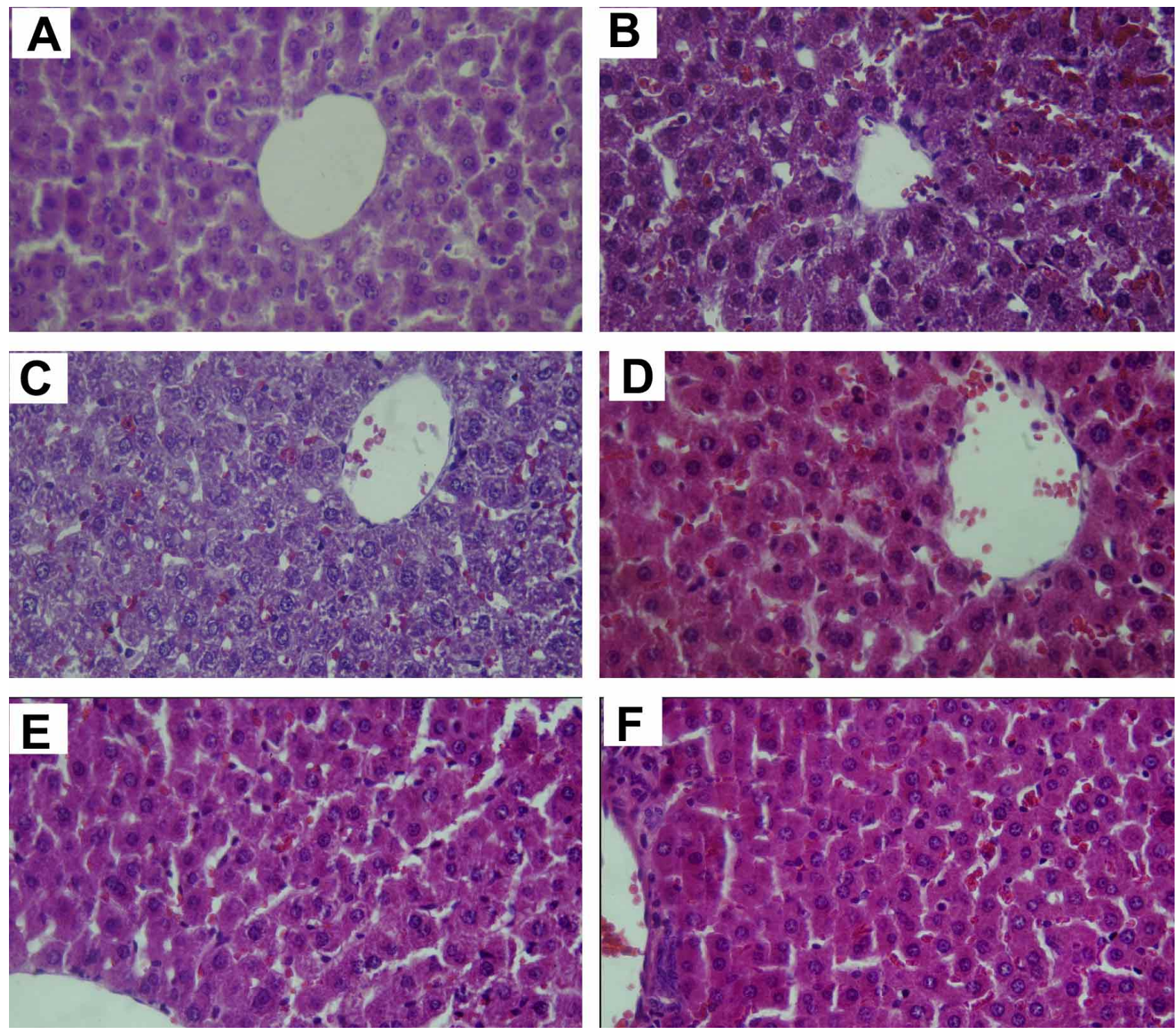

Fig. 3. Histological microphotographs of liver sections (60x) in (A) healthy rats fed with standard diet, (B) metabolic syndrome analogyinduced rats fed with StD, and metabolic syndrome analogy-induced rats fed with StD plus (C) guava-strawberry, (D) guava-blackberry (GBP), (E) guava-soursop fruit (GSSP) or (F) guava-passion fruit (GPP) puree.

\section{CONCLUSION}

The consumption of fruit purees decreased body weight of individual rats with MS, as well as total cholesterol and triacylglycerols, VLDL-C and LDL-C. The StD+FP diets controlled the secretion of insulin, decreased plasma glucose concentrations, and induced an anti-inflammatory effect in the liver, with a significant decrease in ALT, ALP and GGT activities. The diet enriched with guava-blackberry puree caused the best results on most biochemical markers of MS rats. The addition of the four fruit purees to a diet low in fat could be an alternative to decrease body weight and chronic degenerative diseases in individuals with metabolic syndrome.

\section{ACKNOWLEDGEMENTS}

We thank the Company Purés y Derivados de Nayarit for donating the raw materials. This work was supported by Tecnológico Nacional de México (Grant no. 6173.17-P) and CONACYT-Mexico (Grant no. 211953). 
MORALES-ÁVILA, U. M.; YAHIA, E. M.; MONTALVO-GONZÁLEZ, R.; BECERRA-VERDÍN, E. M. \& MONTALVO-GONZÁLEZ, E. Efecto de dietas bajas en grasa enriquecida con purés de frutas sobre marcadores bioquímicos en ratas inducidas con analogia a sindrome metabólico. Int. $J$. Morphol., 38(1):61-68, 2020.

RESUMEN: Los purés de frutas se pueden agregar a la dieta como fuentes alternativas de compuestos bioactivos para la prevención y / o mejora de las complicaciones del síndrome metabólico. En este trabajo evaluamos el efecto de la ingesta de dietas bajas en grasas, enriquecidas con purés de frutas (guayaba-fresa, guayaba-mora, guayaba-guanábana, guayaba-maracuyá) sobre el peso corporal y los marcadores bioquímicos en el síndrome metabólico (SM) inducido en ratas. Las ratas ( $\mathrm{n}=6$ para cada tratamiento) fueron inducidas con una dieta alta en grasas y se les inyectó estreptozotocina, una dosis cada semana durante 4 semanas consecutivas después de ayunar durante la noche. Luego, las ratas sanas fueron alimentadas con una dieta estándar; y las ratas con SM fueron alimentadas con dieta estándar más cada uno de los purés de frutas, durante 4 semanas. Como hallazgos novedosos, la dieta enriquecida con purés de frutas se asoció con una reducción en el peso corporal $(\sim 13-21 \%)$ y un control en el metabolismo de la glucosa al disminuir la glucosa en plasma $(\sim 59-63 \%)$. Además, hubo una reducción en el colesterol total, triacilgliceroles, lipoproteínas de baja densidad, y bajas actividades enzimáticas de alanina aminotransferasa, fosfatasa alcalina y gama-glutamil transferasa, metabolitos útiles en el control de los procesos inflamatorios en el hígado. Se observó una mejora notable en la morfología del hígado, lo que indica que los tratamientos tuvieron un efecto hepatoprotector. La dieta enriquecida con puré de guayaba y mora causó los mejores resultados en la mayoría de los marcadores bioquímicos de las ratas con SM. Por lo tanto, las dietas enriquecidas con purés de frutas pueden ser una alternativa para las personas con SM, para el control y la mejora de las complicaciones causadas por este síndrome.

PALABRAS CLAVE: Marcadores bioquímicos; Purés de frutas; Efecto hepatoprotector; Síndrome metabólico.

\section{REFERENCES}

Brownlee, M.; Aiello, L. P.; Cooper, M. E.; Vinik, A. I.; Plutzky, J. \& Boulton, A. J. M. Complications of Diabetes Mellitus. In: Melmed, S.; Polonsky, K. S.; Larsen, P. R. \& Kronenberg, H. (Eds.). Williams Textbook of Endocrinology. $13^{\text {th }}$ ed. Philadelphia, Elsevier, 2016. pp.1484-581

Carillon, J.; Romain, C.; Bardy, G.; Fouret, G.; Feillet-Coudray, C.; Gaillet, S.; Lacan, D.; Cristol, J. P. \& Rouanet, J. M. Cafeteria diet induces obesity and insulin resistance associated with oxidative stress but not with inflammation: improvement by dietary supplementation with a melon superoxide dismutase. Free Radic. Biol. Med., 65:254-61, 2013.

Choi, H.; Kim, H. C.; Song, B. M.; Park, J. H.; Lee, J. M.; Yoon, D. L.; Yoon, Y. M.; Rhee, Y.; Youm, Y. \& Kim, C. O. Serum uric acid concentration and metabolic syndrome among elderly Koreans: The Korean Urban Rural Elderly (KURE) study. Arch. Gerontol. Geriatr., 64:51-8, 2016.

de Oliveira, L. S.; Thomé, G. R.; Lopes, T. F.; Reichert, K. P.; de Oliveira, J. S.; da Silva Pereira, A.; Baldissareli, J.; da Costa Krewer, C.; Morsch, V. M.; Chitolina Schetinger, M. R.; et al. Effects of gallic acid on delta - aminolevulinic dehydratase activity and in the biochemical, histological and oxidative stress parameters in the liver and kidney of diabetic rats. Biomed. Pharmacother., 84:1291-9, 2016.

Diario Oficial. NORMA Oficial Mexicana NOM-062-ZOO-1999, Especificaciones técnicas para la producción, cuidado y uso de los animales de laboratorio. Ciudad de México, Diario Oficial, 2001. pp.107-65. Available from: https:// www.gob.mx/cms/uploads/attachment/file/203498/NOM-062-ZOO1999_220801.pdf

Díaz-de-Cerio, E.; Rodríguez-Nogales, A.; Algieri, F.; Romero, M.; Verardo, V.; Segura-Carretero, A.; Duarte, J. \& Galvez, J. The hypoglycemic effects of guava leaf (Psidium guajava L.) extract are associated with improving endothelial dysfunction in mice with diet-induced obesity. Food Res. Int., 96:64-71, 2017.

Durner, L.; Bourdoumis, A. \& Buchholz, N. Metabolic syndrome and urolithiasis. Comptes Rendus Chimie, 19(11-12):1451-5, 2016.

Fishbein, M. H.; Miner, M.; Mogren, C. \& Chalekson, J. The spectrum of fatty liver in obese children and the relationship of serum aminotransferases to severity of steatosis. J. Pediatr. Gastroenterol. Nutr., 36(1):54-61, 2013.
Houben, T.; Brandsma, E.; Walenbergh, S. M. A.; Hofker, M. H. \& Shiri-Sverdlov, R. Oxidized LDL at the crossroads of immunity in non-alcoholic steatohepatitis. Biochim. Biophys. Acta Mol. Cell Biol. Lipids, 1862(4):416-29, 2017.

Jankovic, A.; Korac, A.; Buzadzic, B.; Otasevic, V.; Stancic, A.; Daiber, A. \& Korac, B. Redox implications in adipose tissue (dys)function--A new look at old acquaintances. Redox Biol., 6:19-32, 2015.

Jin, S. M.; Hong, Y. J.; Jee, J. H.; Bae, J. C.; Hur, K. Y.; Lee, M. K. \& Kim, J. H. Change in serum albumin concentration is inversely and independently associated with risk of incident metabolic syndrome. Metabolism, 65(11):1629-35, 2016.

Khanam, P. A.; Hoque, S.; Begum, T.; Habib, S. H. \& Latif, Z. A. Microvascular complications and their associated risk factors in type 2 diabetes mellitus. Diabetes Metab. Syndr., 11 Suppl. 2:S577-81, 2017.

Klimis-Zacas, D.; Vendrame, S. \& Kristo, A. S. Wild blueberries attenuate risk factors of the metabolic syndrome. J. Berry Res., 6(2):225-36, 2016.

Liu, X.; Harada, N.; Yamane, S.; Kitajima, L.; Uchida, S.; Hamasaki, A.; Mukai, E.; Toyoda, K.; Yamada, C.; Yamada, Y.; et al. Effects of long-term dipeptidyl peptidase-IV inhibition on body composition and glucose tolerance in high fat diet-fed mice. Life Sci., 84(25-26):876-81, 2009.

Maulucci, G.; Daniel, B.; Cohen, O.; Avrahami, Y. \& Sasson, S. Hormetic and regulatory effects of lipid peroxidation mediators in pancreatic beta cells. Mol. Aspects Med., 49:49-77, 2016.

Pérez-Beltrán, Y. E.; Becerra-Verdín, E. M.; Sáyago-Ayerdi, S. G.; Rocha-Guzmán, N. E.; García-López, E. G.; Castañeda-Martínez, A.; Montalvo-González, R.; Rodríguez-Aguayo, C. \& Montalvo-González, E. Nutritional characteristics and bioactive compound content of guava purees and their effect on biochemical markers of hyperglycemic and hypercholesterolemic rats. J. Funct. Foods, 35:447$57,2017$.

Rubin, R. \& Strayer, D. Patología. Fundamentos Clínicos Patológicos en Medicina. $6^{\text {th }}$ ed. Madrid, Wolters Kluwer/Lippincott Williams \& Wilkins, 2012.

Samout, N.; Bouzenna, H.; Dhibi, S.; Ncib, S.; ElFeki, A. \& Hfaiedh, N. Therapeutic effect of apple pectin in obese rats. Biomed. Pharmacother., 83:1233-8, 2016.

Sawicka, M.; Janowska, J. \& Chudek, J. Potential beneficial effect of some adipokines positively correlated with the adipose tissue content on the cardiovascular system. Int. J. Cardiol., 222:581-9, 2016.

Shahidi, F. \& Ambigaipalan, P. Phenolics and polyphenolics in foods, beverages and spices: Antioxidant activity and health effects - A review. J. Funct. Foods, 18 (Part B):820-97, 2015

Siri-Tarino, P. W. \& Krauss, R. M. The early years of lipoprotein research: from discovery to clinical application. J. Lipid Res., 57(10):1771-7, 2016.

Siriwardhana, N.; Kalupahana, N. S.; Cekanova, M.; LeMieux, M.; Greer, B. \& Moustaid-Moussa, N. Modulation of adipose tissue inflammation by bioactive food compounds. J. Nutr. Biochem., 24(4):613-23, 2013.

Tsitsimpikou, C.; Tsarouhas, K.; Kioukia-Fougia, N.; Skondra, C.; Fragkiadaki, P.; Papalexis, P.; Stamatopoulos, P.; Kaplanis, I.; Hayes, W. A.; Tasatsakis, A.; et al. Dietary supplementation with tomato-juice in patients with metabolic syndrome: a suggestion to alleviate detrimental clinical factors. Food Chem. Toxicol., 74:9$13,2014$.

Ullah, N.; Hafeez, K.; Farooq, S.; Batool, A.; Aslam, N.; Hussain, M. \& Ahmad, S Anti-diabetes and anti-obesity: A meta-analysis of different compounds. Asian Pac. J. Trop. Dis., 6(9):749-56, 2016.

Vahid, F.; Zand, H.; Nosrat-Mirshekarlou, E.; Najafi, R. \& Hekmatdoost, A. The role dietary of bioactive compounds on the regulation of histone acetylases and deacetylases: a review. Gene, 562(1):8-15, 2015.

World Health Organization (WHO). Diabetes. Geneva, World Health Organization, 2016. Available from: http://www.who.int/mediacentre/factsheets/fs312/en/

\section{Corresponding author:}

Efigenia Montalvo-González

Laboratorio Integral de Investigación en Alimentos

Tecnológico Nacional de México

Instituto Tecnológico de Tepic

Tepic, Nayarit

MÉXICO

\section{Email: efimontalvo@gmail.com eduardo.becerra@uan.edu.mx}

Received: 08-07-2019

Accepted: 03-08-2019 